\title{
Implementation of Education and Education Manpower Recruitment Patterns In Sdit Al-Ihsan Baleendah Bandung
}

\author{
Neni Nadiroti Muslihah', Alamsyah Nurseha², Ejen Jenal Mutaqin ${ }^{3}$, Lutfi Asy'ari ${ }^{4}$ \\ 1,3,4 Institut Pendidikan Indonesia (IPI) Garut \\ ${ }^{2}$ STIT Al-Ihsan Baleendah \\ neninadiroti@institutpendidikan.ac.id
}

\section{Article History}

accepted 05/11/2020

approved 10/11/2020

published 01/02/2021

\begin{abstract}
Educators and education personnel are one of the most important elements in improving the quality of education. Human resources are important in achieving the goals of an institution or organization, because $H R$ is the driving force of other resources. Competition between Integrated Islamic Primary Schools in Bandung Regency, especially in Baleendah District will have an impact on the quality of recruitment of Educators and Education Personnel, as has been done by SDIT Al-Ihsan Baleendah. The focus of this study is the analysis of the recruitment of teaching staff and education personnel at SDIT Al-Ihsan Baleendah. This study aims to capture the recruitment strategy carried out by SDIT Al-Ihsan Baleendah. This type of research is a qualitative descriptive study. In the data collection technique, various techniques were used in this study, namely interviews, observation and documentation. The data analysis procedure used in this study was qualitative analysis. Based on the findings from the research results, it was concluded that the implementation of recruitment at SDIT Al-Ihsan Baleendah was carried out through administrative tests, interviews and practice stages.
\end{abstract}

Keywords: recruitment, sdit, recruitment quality

\begin{abstract}
Abstrak
Tenaga pendidik dan tenaga kependidikan merupakan salah satu unsur terpenting dalam meningkatkan mutu pendidikan. Sumber daya manusia merupakan hal penting dalam pencapaian tujuan suatu lembaga maupun organisasi, karena SDM merupakan penggerak dari sumber daya yang lainnya. Persaingan antar Sekolah Dasar Islam Terpadu di Kabupaten Bandung, khususnya di Kecamatan Baleendah akan berdampak pada kualitas rekrutmen Tenaga Pendidik dan Tenaga Kependidikan, seperti halnya yang dilakukan oleh SDIT AI-Ihsan Baleendah. Fokus penelitian ini adalah analisis rekrutmen tenaga pendidik dan tenaga kependidikan di SDIT Al-Ihsan Baleendah. Penelitian ini bertujuan untuk memotret strategi rekrutmen yang dilakukan oleh SDIT Al-Ihsan Baleendah. Jenis penelitian ini merupakan penelitian deskriptif kualitatif. Dalam teknik pengumpulan data pada penelitian ini dipergunakan berbagai teknik, yaitu wawancara, observasi, dan dokumentasi. Prosedur analisis data yang digunakan dalam penelitian ini analisis kualitatif. Berdasarkan temuan dari hasil penelitian, disimpulkan pelaksanaan rekrutmen di SDIT AI-Ihsan Baleendah dilaksanakan dengan tahap tes administrasi, wawancara dan praktek.

Kata kunci: rekrutmen, sdit, kualitas rekrutmen
\end{abstract}

Social, Humanities, and Education Studies (SHEs): Conference Series https://jurnal.uns.ac.id/shes

p-ISSN 2620-9284

e-ISSN 2620-9292 


\section{PENDAHULUAN}

Memasuki era globalisasi yang ditandai dengan berbagai kemajuan pada bidang-bidang tertentu dalam kehidupan manusia, menuntut masyarakat untuk mempersiapkan diri untuk memiliki daya saing yang penuh supaya mampu memanfaatkan peluang-peluang yang ada di lingkungan mereka. Sehingga mereka akan dapat bertahan hidup dan dapat menyesuaikan dengan perkembangan zaman yang akan semakin modern.

Negara Indonesia telah memiliki landasan yang cukup kuat dalam menata pendidikan nasional kita. Berdasarkan pada Undang Undang No. 20 tahun 2003 tentang Sistem Pendidikan Nasional (SISDIKNAS), Indonesia di harapkan mampu memajukan pendidikannya. Dalam undang-undang ini "Pendidikan adalah usaha sadar dan terencana untuk mewujudkan suasana belajar dan proses pebelajaran agar peserta didik secara aktif mengembangkan potensi dirirnya untuk memiliki kekuatan spiritual keagamaan, pengendalian diri, kepribadian, kecerdasan, akhlak mulia, serta keterampilan yang diperlukan dirinya, masyarakat, bangsa dan negara".

Lembaga pendidikan seperti halnya Sekolah Dasar akan dapat mencapai tujuan seperti apa yang diharapkan masyarakat apabila didukung oleh beberapa hal seperti adanya sarana prasarana, dana, dan sumber daya manusia yang berkualitas dan handal. Sumber daya manusia merupakan hal penting dalam pencapaian tujuan suatu lembaga maupun organisasi, karena SDM merupakan penggerak dari sumber daya yang lainnya.

Berbicara mengenai sumber daya manusia, menurut Notoatmojo $(2009, \mathrm{hlm} .1)$ sebenarnya dapat di lihat dari dua aspek, yakni aspek kuantitas dan aspek kualitas. Aspek kuantitas bersangkutan dengan jumlah sumber daya manusia atau penduduknya itu sendiri. Sedangkan aspek kualitas bersangkutan dengan mutu sumber daya manusia tersebut yang di dalamnya terdapat kemampuan baik fisik maupun non fisik.

Pendidik dalam hal ini yang langsung berhadapan dengan peserta didik haruslah pendidik yang benar-benar profesional dalam bidangnya. Hal ini di dukung oleh UU Sisdiknas No. 20 tahun 2003 Pasal 42 ayat (1) menyebutkan pendidik harus memiliki kualifikasi minimum dan sertifikasi sesuai dengan jenjang kewenangan mengajar, sehat jasmani dan rohani, serta memiliki kemampuan untuk mewujudkan tujuan pendidikan nasional. Dari uraian pasal 42 tersebut sudah cukup jelas bahwa untuk menjadi seorang pendidik bukan hal yang mudah, sebagai tahapan awal seorang pendidik harus memenuhi syarat kualifikasi yang telah di tentukan. Baru pada tahapan berikutkan seorang pendidik akan di uji kompetensi yang dimiliki.

Begitu pula dalam Standar Tenaga Administrasi Sekolah/Madrasah Nomor 24 tahun 2008. Tenaga Administrasi terdiri atas Kepala Tenaga Administrasi, Pelaksana Urusan, dan petugas layanan dengan kualifikasi berstandar, dan memiliki standar kompetensi.

Manajemen Sumber Daya Manusia akan memperoleh hasil yang maksimal, apabila dilaksanakan melalui prosedur yang baik, diantaranya: proses perencanaan SDM, seleksi, penempatan, pemberian kompensasi, penghargaan, pendidikan dan latihan pengembangan dan pemberhentian. Manajemen Sumber Daya Manusia bertujuan untuk mengatur dan mengelola sumber daya manusia yang bermutu, handal, produktif, dan berprestasi.

Rokhmaniyah (2017), aktivitas manajemen SDM dalam suatu lembaga organisasi meliputi: perencanaan SDM, rekrutmen, seleksi, penempatan, pelatihan dan pengembangan, penilaian kinerja, sistem imbalan/kompensasi, pemeliharaan hubungan kerja, dan pemutusan hubungan kerja. Jadi, dapat disimpulkan bahwa manajemen sumber daya manusia adalah suatu proses perencanaan, pengorganisasian (penempatan), penggerakan dan pengawasan terhadap pengadaan (rekruitmen dan seleksi), pengembangan, pemberian kompensasi, pengintegrasian, 
pemeliharaan dan pemutusan hubungan kerja pegawai untuk mencapai tujuan organisasi yang efektif dan efisien. Sumber daya manusia dalam penelitian ini dibatasi pada pendidik dan tenaga kependidikan.

Selanjutnya Kurnaengsih (2015), berbicara Sekolah Dasar, di beberapa tahun belakangan tidak sedikit penyelenggara Sekolah Dasar membangun penyelenggaraan layanan pendidikan tingkat Sekolah Dasar berbasis Islam Terpadu. Sekolah-sekolah Islam Terpadu menarik untuk diteliti setidaknya karena sejumlah hal berikut. Pertama merebaknya sekolah jenis ini adalah adanya fenomena santrinisasi.

Muncul dan berkembangnya Sekolah-sekolah Islam Terpadu tampaknya memiliki dampak yang berjangkauan luas terhadap masa depan masyarakat Muslim Indonesia. Sekolah-sekolah yang menawarkan pendidikan berkualitas tersebut tidak hanya memberi kontribusi pada perbaikan pendidikan Islam di Indonesia, melainkan juga pada proses santrinisasi masyarakat Muslim. Proses santrinisasi itu dapat digambarkan terjadi melalui dua cara,

Sekolah Dasar Islam Terpadu Al-Ihsan Baleendah, merupakan salah satu yang paling terkenal dan eksis di daerah Baleendah, Kabupaten Bandung. Dalam beberapa tahun terakhir SDIT Al-Ihsan Baleendah mengalami banyak kemajuan termasuk pada prestasi raihan siswa/i-nya. Hal ini diindikasikan dengan adanya pemenuhan kualitas dan kuantitas SDM baik Guru dan tenaga kependidikan di SDIT AI-Ihsan Baleendah. Dengan alasan inilah peneliti ingin lebih mengetahui tentang Manajemen SDM yang ada di SDIT Al-Ihsan Baleendah dalam mengelola dan menghasilkan prestasi.

\section{METODE}

Penelitian ini menggunakan pendekatan fenomenologi dengan jenis penelitian deskriptif kualitatif, yang merupakan prosedur penelitian dengan data deskriptif berupa kata tertulis atau lisan dari orang-orang dan perilaku yang diamati (Moleong, 2014). Peneliti melihat dan memahami subyek dan obyek penelitian berdasarkan fakta apa adanya untuk mengumpulkan data, menyajikan informasi kemudian mendeskripsikan keadaan "Implementasi Pola Rekruitmen Tenaga Pendidik dan Tenaga Kependidikan di SDIT Al-Ihsan Baleendah Bandung" kemudian menarik kesimpulan berdasarkan ketentuan yang ditetapkan.

Objek dalam penelitian ini adalah SDIT AI-Ihsan Baleendah yang difokuskan pada pola rekruitmen Tenaga Pendidik dan Tenaga Kependidikan. Subjek penelitiannya adalah sumber tempat kita memperoleh keterangan penelitan sesuai dengan pendapat Amirin (1993). Selanjutnya, menurut Arikunto (2018) subjek penelitian adalah benda, hal atau orang tempat data untuk variable melihat, dan yang dipermasalahkan, dalam penelitian ini adalah Kepala Sekolah, beberapa Guru dan beberapa orang karyawan (tenaga kependidikan).

Teknik observasi partisipatif, peneliti langsung mengamati apa yang terjadi di SDIT Al-Ihsan Baleendah Kabupaten Bandung untuk mengamati dan memahami serta mencatat berbagai aspek yang berkaitan dengan rekruitmen tenaga pendidik dan tenaga kependidikan. Pedoman wawancara yang digunakan berupa garis besar permasalahan yang akan ditanyakan (Sugiyono, 2014, hlm. 320). Selebihnya peneliti mengumpulkan berbagai dokumentasi pendukung analisa. Hal tersebut di atas mempermudah peneliti melakukan analisis data melalui proses reduksi data, penyajian data dan menarik kesimpulan (Hadi, 1986).

\section{HASIL DAN PEMBAHASAN}

Meskipun saat ini persaingan dalam bidang pendidikan cukup ketat, baik dari segi jumlah sekolah yang semakin banyak sampai dengan persaingan dalam hal biaya pendidikan yang ditawarkan setiap sekolahpun cukup bersaing. Namun jumlah peserta didik di SDIT Al-Ihsan Baleendah sangat stabil pada tahun pertama. Hal ini dapat 
berarti bahwa tingkat kepercayaan masyarakat terhadap hasil pendidikan disekolah ini cukup baik.

Tenaga Pendidik dan Kependidikan dalam hal ini guru dan staf pegawai lainnya merupakan syarat mutlak dalam organisasi kependidikan. SDIT Al-Ihsan Baleendah berusaha untuk memberikan bimbingan secara maksimal kepada siswa dan wali murid (orang tua) dan pihak lain yang membutuhkan pelayanan lembaga dengan menghadirkan Sumber Daya Manusia yang kompeten dibidangnya, professional dan bertanggungjawab. Walaupun beragam, latarbelakang tenaga pendidik dan tenaga kependidikan di SDIT Al-Ihsan Baleendah mayoritas berasal dari latar belakang keguruan, namun hal ini tidak menjadi kendala berarti bagi lembaga karena lembaga menyediakan keleluasaan untuk ikut serta dalam program pengembangan atau peningkatan keprofesionalan SDM. Sehingga kualitas pendidikan yang ditawarkan mampu bersaing dengan lembaga pendidikan lain di sekitarnya.

Jika dilihat dari Perencanaan rekrutmen, SDIT Al-Ihsan Baleendah menyusun perencanaan seperti pengumpulan data, pencatatan dan analisis data, serta merumuskan keputusan. Hal tersebut dilakukan dalam rangka analisis pekerjaan dan analisis jabatan. Dengannya, SDIT Al-Ihsan Baleendah dengan mudah mendapatkan data-data mengenai formasi yang kosong. Berapa jumlah pegawai yang dibutuhkan, dan untuk menentukan persyaratan minimum yang perlu dimiliki pegawai.

Berdasarkan wawancara, pelaksanaan rekruitmen tenaga pendidik dan tenaga kependidikan di SDIT Al-Ihsan Baleendah dilakukan sepenuhnya oleh pihak sekolah. Dengan tetap menyusun terlebih dahulu perencanaan spesifikasi minimal pegawai baru. Pelaksaan rekruitmen itu pun dilakukan di setiap awal tahun pelajaran. Namun, jika tidak ada kekosongan pegawai, maka SDIT Al-Ihsan Baleendah akan memilih program peningkatan keprofesionalan.

Berdasarkan wawancara dengan Kepala Sekolah SDIT AI-Ihsan Baleendah, persiapan yang dilakukan dalam pelaksanaan rekruitmen dan seleksi tenaga pendidik dan kependidikan ini adalah dengan menganalisis tingkat kebutuhan, antara lain menganalisis posisi jabatan yang kosong, jumlah posisi yang kosong, peningkatan jumlah siswa, mutasi pegawai (keluar atau meninggal dunia), penentuan spesifikasi dan menentukan persyaratan yang harus dipenuhi pelamar.

Masih dari hasil wawancara, SDIT Al-Ihsan Baleendah membuka lowongan yang dilakukan dengan mempublikasikan melalui pemasangan berita di madding sekolah, atau media jaringan sekolah. Dari hasil wawancara dengan salah satu guru yang diterima menjadi pegawai SDIT Al-Ihsan Baleendah, beliau mengutarakan mendapatkan informasi tersebut dari salah satu media komunikasi antar jaringan Pesantren di Kabupaten Bandung.

Setelah mengumpulkan berbagai persyaratan administrasi, SDIT Al-lhsan Baleendah mengumpulkan dan menganalisis data yang terkumpul. Hal tersebut untuk mempermudah dalam proses seleksi dan pemberitahuan pengumuman atau panggilan tahap selanjutnya.

Selain tahap pengumpulan berkas administrasi, panitia Rekruitmen Pegawai SDIT Al-Ihsan Baleendah pun telah menyiapkan proses tes. Salah satunya ialah tes wawancara untuk mendapatkan informasi yang belum didapatkan dari data berkas administrasi pelamar. Wawancara itu pun lebih didominasi tentang kepribadian, komitmen keislaman, dan kemampuan pengajarannya.

Jenis wawancara yang digunakan adalah semi terstruktur yaitu pedoman wawancara yang dikembangkan sendiri oleh masing-masing pewawancara. Wawancara pertama perihal kepribadian dalam rangka kejaran nilai teladan bagi setiap pendidik di depan peserta didik. Kepribadian ini mencakup jati diri, akhlak, dan komitmen dari calon pegawai.

Wawancara yang kedua, mengungkapkan keislaman dan keagamaan dari calon pegawai. Karena SDIT Al-Ihsan Baleendah merupakan lembaga pendidikan 
Islam, maka pegawai yang bergabung harus memiliki pemahaman keislaman yang baik dan kuat. Cara yang dilakukan oleh pewawancara di SDIT Al-Ihsan Baleendah ialah dengan tes langsung berupa membaca Al Quran, hafalan surat-surat, hafalan doa-doa.

Sedangkan pada wawancara ketiga, untuk mengungkapkan kompetensi dari calon pegawai. Kompetensi ini untuk melihat kemampuannya di bidang studinya dan kemampuan paedagogiknya. Pewawancara bertanya seputar materi pelajaran Sekolah Dasar dengan pertanyaan yang berkaitan dengan pengintegrasian ke Islaman dalam setiap mata pelajaran. Selain itu, pewawancara akan menilai dari calon pegawai tersebut bagaimana cara berbicara, berkomunikasi, menjawab pertanyaan dan juga penampilannya.

Berdasarkan wawancara dengan salah satu guru SDIT Al-Ihsan Baleendah, benar proses seleksi dilakukan 3 tahap. Wawancara tentang kepribadian, tentang komitmen keislaman, dan kemampuan bidang studinya.

Penilaian akhir, penggabungan nilai dari masing-masing pewawancara. Tes ketiga adalah tes praktek mengajar, sekolah akan menentukan tempat, jadwal, dan materi yang harus disampaikan. Dilakukannya tes mengajar ini untuk melihat kemampuan calon pendidik mengajar di kelas seperti kemampuan dasar mengajarnya, persiapan pengajaran, penguasaan materi, metode yang digunakan dan pengelolaan kelasnya.

Tes mengajar tersebut dilakukan di depan siswa selama 1 jam pelajaran penuh. Selama tes tersebut, calon pendidik akan diamati oleh guru yang kredibel dalam penilaian dana tau oleh wakil kepala bidang kurikulum.

Pada tahapan terakhir, pengumuman diterima atau tidaknya pelamar di SDIT Al-Ihsan Baleendah. Nilai yang diumumkan ialah nilai komulatif dari nilai administrasi, nilai wawancara, dan nilai praktek mengajar. Setelah nilai tersebut terkumpul, pihak sekolah akan menghubungi pihak pelamar yang dinyatakan lolos maupun yang tidak lolos, baik tenaga pendidik maupun tenaga kependidikan.

\section{SIMPULAN}

Berdasarkan temuan hasil penelitian dan pembahasan maka hasil penelitian ini dapat disimpulkan bahwa pelaksanaan rekrutmen dan seleksi tenaga pendidik dan kependidikan di SDIT Al-Ihsan Baleendah telah dilaksanakan sesuai tahapan-tahapan rekrutmen dan seleksi yang ditentukan. Mulai dari tahapan perencanaan, analisis jabatan yang dibutuhkan, dan menentukan persyaratan.

Metode dan teknik rekrutmen yang dilakukan SDIT Al-Ihsan Baleendah adalah metode teori keputusan yaitu metode badan eksekutif yang menetapkan calon yang akan direkrut dan berapa banyak yang dibutuhkan. Sedangkan teknik yang digunakan adalah teknik desentralisasi. Tahapan proses seleksi di SDIT AI-Ihsan Baleendah yaitu proses seleksi administrasi, tes wawancara, dan tes praktek.

Kegiatan rekrutmen ini dilakukan dengan sebaik-baiknya demi tersedianya Sumber Daya Manusia yang bermutu di SDIT Al-Ihsan Baleendah. Walaupun demikian, tidak sepenuhnya dilakukan di setiap tahun pelajaran, hal tersebut disesuaikan dengan perkembangan kebutuhan pegawai di setiap tahunnya.

\section{DAFTAR PUSTAKA}

Amirin, Tatang M. (1990). Menyusun Rencana Penelitian. Jakarta: Rajawali Press. Arikunto, Suharsimi. (2018). Matodologi Penelitian. Jakarta: Rineka Cipta. Hadi, Sutrisno. (1986). Statistik II. Yogyakarta: UGM Press.

Kurnaengsih. (2015). Konsep Sekolah Islam Terpadu, Jurnal Pendidikan dan Studi Islam, Vol ,1, Vol. 1, Desember 2015. ISSN. 2085-2487. 
Moleong, Lexi J. (2014). Metodologi Penelitian Kualitatif. Bandung: PT Remaja Rosdakarya.

Notoatmojo, Soekidjo. (2009). Pengembangan Sumber Daya Manusia. Jakarta: Rineka Cipta.

Rokhmaniyah, (2017). Manajemen Sumber Daya Manusia Untuk Mencapai Pendidikan Yang Berkualitas Di Sekolah Dasar. DWIJACENDEKIA Jurnal Riset Pedagogik 1 (1) (2017) 73-83, p-ISSN 2581-1843 e-ISSN 2581-1835.

Sugiyono. (2014). Metode Penelitian Pendidikan. Jakarta: Rineka Cipta.

. (2013). Undang-Undang SISDIKNAS No. 20 Tahun 2003. Jakarta: Redaksi Sinar Grafika. 